OPEN ACCESS

International Journal of Management \& Entrepreneurship Research

P-ISSN: 2664-3588, E-ISSN:2664-3596

Volume 2, Issue 5, P.No. 391-400, October, 2020

Fair East Publishers

Journal Homepage: www.fepbl.com/index.php/ijmer

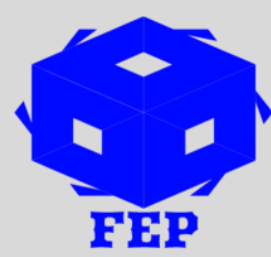

\title{
EMERGENCE OF ECONOMIC INTELLIGENCE APPROACH IN WEST AFRICA: CASE OF A TELCO IN BURKINA FASO
}

\author{
Dr. Honoré Ouédraogo ${ }^{1}$, Dr. Théophile Bindeouè Nassè ${ }^{2,3}$ \\ ${ }^{1}$ Université Ouaga $3 \mathrm{~S}$, Ouagadougou (Burkina Faso) \\ ${ }^{2}$ Thomas Sankara University, Ouagadougou (Burkina Faso) \\ ${ }^{3}$ Saint Thomas University, Ouagadougou (Burkina Faso)
}

\begin{abstract}
*Corresponding Author: Dr. Théophile Bindeouè Nassè
Corresponding Author Email: nassetheophile2009@ gmail.com

Article Received: 25-09-20

Accepted: $10-10-20$
\end{abstract}

Published: $15-10-20$

Licensing Details: Author retains the right of this article. The article is distributed under the terms of the Creative Commons Attribution-NonCommercial 4.0 License (http://www.creativecommons.org/licences/by-nc/4.0/) which permits non-commercial use, reproduction and distribution of the work without further permission provided the original work is attributed as specified on the Journal open access page.

\begin{abstract}
This paper focuses on the relationship between economic intelligence (EI, understood in the informational sense of the term, Martre (1994) and performance. It raises the question of the impact of the deployment of EI on improving the company's results. Our theoretical approach is based on the corpus of management of the EI system, which is a dedicated IS. The epistemological positioning is of the constructivist type and the methodological approach, of the qualitative type. As for our approach, it is based on an exploration based on a case study in the mobile phone sector investigated in 2018 in Burkina Faso, especially in the city of Ouagadougou. Our results show that steering the dynamics of EI improves the performance of the organization in the terms of achieving pre-established objectives. This case study addresses its own limits and it may be subject to some extensions in the future
\end{abstract}

Keywords: Economic Intelligence, Monitoring, Protection, Influence, Mobile Telephony

\section{INTRODUCTION}

Faced with a multipolar, ultra-competitive world (Nassè, 2019), marked by ever-growing uncertainty and based on information, organizational actors are rethinking the organization and functioning of the enterprise. The extent of the upheavals caused by the globalization of trade can no longer be controlled within the framework of traditional organizations. The apprehension of complex and uncertain environments requires a review of the thinking methods and behaviors of all economic players. The information society, also called the knowledge society, refers to a state of society in which ICTs play a leading role. We can 
rightly speak of "iconomy"(Volle, 2014), a society whose economy, institutions and lifestyles are based on the synergies of microelectronics, software and the Internet.

Bidan (2017), specifies that this digital economy is a heavy industry both literally and figuratively. It is nothing less than this economy which wants to be without being, that of the intangible. Economic intelligence (EI) is emerging as an alternative mode of government and management of organizations. Enterprise, being an open system and in permanent interaction with its environment, EI offers a relevant reading grid of this relationship between the company and its environment. The system being considered, according to Le Moigne (1977), " as an organized set of elements in dynamic interaction to achieve a goal."

EI identifies with a strategic decision-making support approach that is a response to contemporary challenges in the context of globalized exchanges.

Mobile telephony, also called cellular telephony, is a means of telecommunication, more precisely of radio communication, by mobile telephone.

In Burkina Faso(BF), the appearance of the cell phone dates back to 1996 thanks to the XIX ${ }^{\text {th }}$ France-Africa Summit.

The telecommunications sector in Burkina Faso is governed by Law No. 061-2008 / AN of November 27, 2008, laying down general regulations for electronic communications networks and services. On the mobile telephone segment, three (03) suppliers currently share the market; these are Onatel SA, Orange Burkina and Telecel Faso, all private operators. Mobile telephony is one of the most flourishing branches of the economy today. The performance and dynamism of the mobile telephony market are significant. With a penetration rate of $95.53 \%$ of the estimated national population for 2018 (Arcep, 2018), the mobile market is royally pursuing its sustained growth due, among other things, to the intensification of competition, the diversification of offers, the extension of networks to localities in the interior and consumption habits. The success of telephony in Burkina Faso has generated a new phenomenon: the majority of subscribers have three (03) chips, i.e. one per operator, promotional offers dictating this reality. The hypercompetitive context and technological advances have given rise to innovative products and services with high added value, bringing together, for example, the mobile telephone and banking. More and more, it is the development of enriched services that is becoming a vector of profitability. It is the point of polarization of energies at this time. The problematic of the EI in Burkina Faso, is part of a burning news as evidenced by the holding of the first edition of the Burkinabè week of economic intelligence (SBIE) from October 7 to 14, 2019 and the start of the development of the national economic intelligence strategy. We postulate that there is a certain constructed reality EI in Telecel Faso. In view of the above, the main question of this research is worded as follows: "To what extent does the deployment of an EI approach contribute to concretely improve the performance of the company?"

The overall objective of this paper is to understand the various perceptions and practices of the EI Telecel Faso and that in order to improve them. Specifically, it is to:

1. describe the perceptions, the perceptions of the concept and the uses of the EI of the organizational actors in their own context;

2. show the positive impact of EI on the performance of the company;

3. locate the IE device of the telco studied according to an elaborate taxonomy. 
Our project aims to understand a complex phenomenon in a particular context for prescription purposes.

\section{LITERATURE REVIEW}

\section{Economic Intelligence and Challenges in West African Companies}

The definition original and official of EI was set by the ratio of the Marten Board XI ${ }^{\text {th }}$ Plan in 1994. It defines it as follows: "All the coordinated actions of research, processing and distribution with a view to its exploitation, of information useful to economic actors. These rights are legally conducted with all protection safeguards required for pre preservation of the heritage of entry e taken in the best conditions of quality, delivery and cost.

The report underlines that the notion of EI implies going beyond partial actions of documentation, monitoring (scientific and technological, competitive, financial, legal and regulatory, etc.), protection and influence.

For Wilensky (1967), “EI is a knowledge production activity serving the economic and strategic goals of an organization, collected and produced in a legal context and from open sources."

EI is a management system adapted to the current challenges of survival, sustainability and development of organizations. According to Baumard (1991), "EI makes it possible to move from a passive organization to an active organization".

The first attempts to raise awareness about EI in Africa date back to 1995. Amath Soumare, promoter of the Sopel international company, is the moderator of the first conferences on EI in Africa.

In the mid-2000s, African graduates from the École de guerre économique de Paris, like Guy Gweth created the first EI firms in sub-Saharan Africa.

It was not until 2009 to witness the launch of a real collective dynamic in Dakar under the leadership of Babacar Diallo, who has headed the branch of the Center for Diplomatic and Strategic Studies (CEDS) there for over ten years). He launched the Pan-African School of Economic Intelligence and Strategy (EPIES) whose first graduates graduated in 2010.

Ivory Coast has a EI public policy since 2011 and it has a significant number of actors in EI (Cabinet Aris -intelligence, Universities, Institutes, Companies, TV channel tray dedicated as Business 24).

It exists in most countries in West Africa of a national EI Association affiliated to the International French EI Association. A broad consensus is emerging around the need to produce a strategic intelligence that sticks to African realities with a clear penchant for raw materials, non-eternal wealth and the strengthening of human capital. In most sub-Saharan countries, monitoring and collecting local information is essentially reduced to monetary human intelligence. In West Africa, EI is perceived as a leading requirement for countries wishing fit effectively into the international economy. It is an essential component of economic development which constitutes one of the challenges of integration into the world economy. Indeed, the acts of EI in West Africa aim both to draw inspiration from foreign experiences and to develop African initiatives while taking into account cultural specificities.

Burkina Faso had an unprecedented experience in West Africa with the collective intelligence network (RIC) in 2011. The IE like material is offered in many universities and business schools. Associations such as the Burkina Faso Association for Innovation and 
Economic Intelligence (ABIIE) and the African Center for Business Intelligence and Intelligence (CAVI E-BF) are working to promote the concept. A national CI strategy is under development. It is managed by the Ministry of the Economy, Finance and Development (MINEFID).

At the $2^{\text {nd }}$ Forum of African EI associations (FAAIE) held in Morocco in June 2019 under the following topic: "Economic intelligence and prospective African territories ", the price of the Masters category was awarded to a student from IUFIC from Ouaga II University. In the Burkina Faso's Chamber of Commerce and Industry (CCI-BF) there is a Department of Foresight and Economic Intelligence, in collaboration with all stakeholders, organized the $1^{\text {st }}$ edition of the Week Burkinabe EI (SIBE). It took place from $07^{\text {th }}-14^{\text {th }}$ October 2019 in Ouagadougou under the theme: "Economic intelligence, state of play, challenges and issues for companies".

As one can see, the issue of EI is one of the hottest news in Burkina Faso.

\section{METHODOLOGY}

We have subscribed to a constructivist trend for the generation of research results. Three (03) schemas were called up and put in parallel: functional, actantial and hermeneutical. Our research method is qualitative in nature based on a case study, in this case the Burkinabè mobile operator Telecel Faso. As such, it generates data for verbal context. The nature of our exploration is of a hybrid type, since it combines concomitantly and iteratively knowledge from the field and theoretical knowledge. We use the qualitative method and for good reason, qualitative methods are well suited to the study of the opinions, behaviors and practices of individuals. "Qualitative research is characterized by a comprehensive aim, which sets itself the objective of understanding the action in a context or in a situation", Dumez (2011).

Our research method is qualitative in nature. As such, it generates data relating to a particular context, in this case telcos (Telecom Company). The semi-structured interview, nonparticipant observation and documentation (written, sound, audiovisual, sound and iconographic) were the methods of data collection. We simultaneously apply the three (03) golden principles of data collection namely triangulation, iteration and saturation (Nassè, 2018; Nassè, 2020).

We constitute a "micro sample" composed of fifteen (15) people. As tools for empirical investigation, we used the logbook, the interview guide and an exosomatic organ, in particular a smartphone. A full transcript of the recorded interviews was carried out using the free application Speech notes. The transcripts of the interviews and the notes resulting from the observation were subjected to a thematic content analysis where the units of analysis retained are the sentence or group of sentence.

The data collected was processed and analyzed in a semi-tooled manner: using ADQAO software, in particular Tropes, version 2018, and manually.

Presentation of Research Field: Mobile telephony was born in Burkina Faso thanks to the XIX $^{\text {th }}$ France-Africa summit held in December 1996. It was launched by the historical operator, ONATEL SA, which until then enjoyed a monopoly privilege. The liberalization of the telecommunications / ICT sector began in the second half of the 1990s. To date, the legal framework for this sector is constituted by Law $\mathrm{N}^{\circ}$ 061-2008 / AN of November 27, 2008, laying down general regulations for electronic communications networks and services. The cellular telephony market in Burkina Faso has three (03) suppliers, namely ONATEL 
sa, Orange BF and Telecel Faso. It is characterized by its significant dynamism favored by ruthless competition with increasingly diversified offers. It is an oligopolistic, dynamic, heterogeneous and growing sector. At the end of the $4^{\text {th }}$ quarter of 2018 , the total fleet of mobile networks amounted to 19,339,109 subscribers (active SIM cards) for all three (03) operators, for a penetration rate of $95.53 \%$ of the estimated national population for 2018 (Arcep, 2018). Note that it is the case of coverage of the population and not of coverage of the area of the territory. The three (03) telcos regularly installed in Burkina Faso are all capital companies. Among the three (03) companies, only Telecel Faso is the company that has a capital that is held exclusively by a national. Telecel Faso, given its Burkinabèstyle success story, is our basis for empirical investigation. Apollinaire Compaoré, founder of the Planor Afrique group to which Telecel Faso belongs, is a leading figure in the business world in Burkina Faso. Born in Koassa in the province of Bam in 1953, Apollinaire Compaoré can neither read nor write. However, he finds himself now ahead of the different largest companies in Burkina Faso and in the West African sub-region. He has invested in telecommunications, insurance, hospitals, distribution, banking, and transports. $\mathrm{He}$ is the founder and Chairman of the Board of Directors of Telecel. A man with principles as simple as they are basic which have favored his economic success: perseverance, daring, faith in God, respect for the partner and the desire to succeed. Its companies have a total of more than a thousand employees in permanent jobs. He is currently the President of the National Council of Burkinabè Patronage. The year 2000 marks the entrance of Telecel Faso in the national scene of telecommunication with a registered capital of 2.5 billion CFA francs (XOF). The characteristics of the licenses held are as follows: $2 \mathrm{G}$ license renewed in 2010 for 10 years and global 3G license obtained in 2017 for 10 years. Telecel Faso is preparing to obtain a $4 \mathrm{G}$ license like the two (02) other telcos (Telecom company).

The Planor Afrique Group (Burkina Faso) is the exclusive shareholder.

To the aforementioned contextual variables, it should be added that the cultural dimension is predominantly bathed in the national culture with traits of active solidarity, of the reverent relationship with hierarchical superiors, of an uncommon and exemplary awareness of the relationship to time unlike the cliché circularity of time.

The levers of action can be summarized in six (06) axes to know the key parts, the structure, the division of labor, the management-coordinating, and decentralization.

As regards the key parts, the Board of Directors, mandating the Chief Executive Officer, manages the company. The hierarchical line is made up of directors and heads of departments. The support function is provided by a department, in this case the technical department in charge of IT (IT). The Director of Strategy and Development reports to the technostructure, which influences the work of others in terms of planning and methods. Among other things, he deals with IE issues. The operational center ensures the activity of the organization. We estimate it at $80 \%$ of Telecel Faso's workforce. The mobile telephone operator is structured according to a functional organization chart. The division of labor follows a professional and non-Taylorist option. We are witnessing a reflection, a permanent adaptation of tools and methods at work. Job performance is boosted by performance or productivity bonuses. The dominant management style is persuasive. Paternalistic spirit also characterizes the leadership style. 
A standardization work process is observed at Telecel because of the degree of formalization advanced imposed by nor my (legislative, regulatory and professional) and integrated software packages. It should be noted a relative centralization of decisions. Decision- making are factual and action. Bounded rationality or decisional irrationality occupies a preponderant place in decision-making processes. All things considered, the configuration organization of Telecel Faso is of the divisional form. Divisional structures are adopted by enterprise like "ours" working in several fields of activity and having subsidiaries abroad. The strategy of diversifying products \& services, geographic areas of intervention and customers (large accounts / small customers) is the corollary of hypercompetitivity (D' Aveni, 1994) generated by economic liberalism. The divisional structure operates under the effect of internal or external growth.

An internal analysis of the organization according to the SWOT matrix highlights the following findings:

-Strengths: As of December 31, 2017, Telecel Faso network had a subscriber base of $3,318,824$ compared to $2,499,631$ in 2016 , ie an increase of 819,193 in absolute value and $32.77 \%$ in relative value. The penetration rate rose from $12.73 \%$ in 2016 to $17 \%$. The values advocated can be summed up as follows: authenticity, creativity, perseverance. Telecel Faso has many assets such as staff competence and professionalism, the value of the brand Telecel, its good reputation and good image, the perceived quality of its services and products, the affirmed willingness and compliance, the funding investments by the Wendkuni International Bank in the same group Planor Africa; the intra network low rates call, the permanent promotional rates, and the ability of sponsoring social and cultural activities.

-Weaknesses: There are weaknesses in any organization and Telecel Faso does make an exception from this assertion. The marginal position in certain segments, in particular mobile money, a relatively small degree of implantation within the territory, can be listed under its limits.

Telecel Faso ambition to offer more in every sense of the word, as evidenced by its slogan "Offer more..." Its organizational values can be summed up in three (03) essential points: Authenticity, creativity and perseverance. They stick to the personal values of the PCA and these values are in line with the aspirations of Burkinabè consumers.

We translate the imagination projected by this company into this: Man can transcend obstacles and succeed.

The external analysis of the environment makes it possible to highlight the following opportunities and threats:

-Opportunities: market growth rate of mobile telephony, legal and regulatory provisions favorable, absence of price war, friendly capital from mobile users.

-Threats: market turbulence, market sensibility, volatile demand, increased perceived quality, obsolete hardwares and more generally of telecommunications infrastructure.

\section{RESULTS AND DISCUSSION}

The empirical investigation has been fruitful in many ways. It has generated significant results. Our results are idiosyncratic as it is the case of the generality of the results resulting from the qualitative method. Table 1 below provides the call market share of three (03) telcos: 
Table 1

Market Shares following the Voice Traffic up to $4^{\text {th }}$ Quarter 2018 (ARCEP)

\begin{tabular}{lll}
\hline Number & Company name & Percentage \\
\hline 01 & Orange Burkina & $41.7 \%$ \\
\hline 02 & Onatel SA & $35.5 \%$ \\
\hline 03 & Telecel Faso & $22.8 \%$ \\
\hline
\end{tabular}

(Source: Fieldwork, 2018)

All three (03) mobile networks have passed around 2.68 billion minutes of outgoing and incoming traffic during the last quarter of 2018 and Telecel Faso holds an acceptable share of 0.61 billion minutes of call in a hypercompetitive universe dominated by global telephony giants (Arcep, 2018).

It should be noted that the average total volume of recorded communications (sending and receiving calls) by active SIM card has increased from 45 to 46 minutes on average per month. This is the average use of the network per active subscription in minutes per month [This is the total volume of traffic (On net + departure + arrival) compared to the fleet of active subscriptions for the same period].

Telecel Faso SA comes first for this indicator with an average of 65 minutes per month of communication volume for an active subscription to this network. He is followed by Orange Burkina Faso SA then Onatel SA with 44 and 42 minutes respectively.

The EI deployed by Telecel allows it to position itself in niches, which ensure its sustainability, performance and competitiveness. All three (03) mobile networks have passed just under 2.68 billion minutes of outgoing and incoming traffic during the last quarter of 2018 .

What about turnover?

Table 2

Market Shares of Operators in Revenue in $4^{\text {th }}$ Quarter 2018 (ARCEP)

\begin{tabular}{lll}
\hline Number & Company name & Percentage \\
\hline 01 & Orange Burkina & $43.4 \%$ \\
\hline 02 & Onatel SA & $38.9 \%$ \\
\hline 03 & Telecel Faso & $17.7 \%$ \\
\hline \multicolumn{2}{l}{ (Source: Fieldwork, 2018) }
\end{tabular}

For a self-made man, unable to read or write, ensuring a flourishing business in a context of tough competition is an unusual EI.

All EI pillars are found in Telecel Faso to know business intelligence or intelligent standby, the protection of heritage material and immaterial and influence (communication, lobbying, influence, notoriety).

"EI remains at the heart of all our decisions... We refuse to converse on sensitive topics with people we don't know”, says Mr. YM of Telecel Faso.

"We are welcoming fewer and fewer interns. Some pseudos- trainees were sent to us by competitors to scrutinize on our innovations, "exclaims $\mathrm{Mr}$. KP Telecel Faso.

"Imagine that we are going to launch a product and that the project can be found in the hands of our competitors, certainly they will take it, and they will achieve it before us and be against us." says Mr. LH Telecel Faso . 
These fragments of verbatim are witnesses of a real practice of IE at our mobile operator.

All in all, EI is an instrument to aid decision-making. A successful company is that one where good decisions are made.

The EI system of Telecel Faso is located at 5 on a maturity scale which counts as 7 taxonomy below.

A seven (07) strata taxonomy of CI devices was constructed relative to the level of maturity:

1. Embryonic EI (no tangible element of EI, knowledge or not of the dynamics of EI) ;

2. EI fragmented (disparate presence of elements of EI, first fruits of EI and SI articulation);

3. EI tackled (gap between rhetoric and practices; limited support for the implementation process ; functional policies);

4. Formalized EI (existence of an EI policy, EI charter, network of actors) ;

5. Advanced EI (EI agent, EI cell, EI manager, budget allocation, cognitive capitalization) ;

6. Consolidated EI (EI department, EI Directorate) ;

7. Mature EI (EI function strategically inserted in the organizational chart, coordination of EI actions / activities; Shared EI culture).

In another way, it emerges that the deployment of an EI approach contributes to improving the performance of the company. The internal validity of the work finds its justification in the adequacy between the problematic, the objectives, the means and the results.

As for the external validity, the transposability of the results is limited to similar organizations. Absolute external validity would be obtained by research producing a universal law. The knowledge produced by this research can be generalized to fellow enterprise in similar contexts. Our work has been designed to provide useful results with minimal generalization claims. Consequently, the transposability of co- constructed knowledge is very limited. The validity of the construct is reinforced by the robustness of the EI referents and the consensus around their aims of supporting decision-making and making the overall approach of the organization intelligent - that is to say - capable of adapting to its environment and to grow sustainably for the benefit of many in an uncertain context.

\section{CONCLUSION}

The conclusions we have reached seem plausible to us. The knowledge generated can be qualified as local. The main legitimacy of local knowledge is the fact that it was developed and understood as obtained during the empirical work carried out in organizations which operate in some particular contexts; from the study of documents, as well as observations, and interviews conducted on different dates, with some actors at a particular given moment in its history, having occupied some functions in such organizations.

The knowledge generated does not in any way claim to be faithful mirrors of the phenomena it is supposed to represent. They are of a nature to maintain and encourage reflection, to some extent illuminate problematic situations, and / or stimulate creative action by showing plausible ways to achieve certain goals. The results of our work have shown that the deployment of EI contributes to improving the performance of the company. Our research is conclusive compared to the general objective formulated at the start because it apprehends the diversity of perceptions and applications of EI in Telecel Faso in a prescriptive aim. 
EI is the noble art of knowing (Watch), of preventing knowing (Protection) and of making known (Influence).

The implementation of an economic intelligence approach always represents an added value. We agree with the assertion of Achab and Harrizi (2013) that goes: "EI is not a fad, but corresponds well to a major imperative for the actors exposed to global competition."

Strategic management sees in EI a new practice impacting the functioning of organizations with a view to increasing their performance (Harriet \& Loïc, 2010; Nassè, 2019; Ampofo, Nassè, \& Akouwerabou, 2020); what is and added value for companies (Carbonell, Nassè, \& Akouwerabou, 2020). Thus, EI approach could also help to improve and to rethink the management methods in West Africa for better results (Carbonell, Nassè, Briceno \& Ouédraogo, 2020).

The present research also brings out the problematic access to the field of empirical investigation because the West African context is a particular context (Nassè, 2012). It was not always easy to administer the maintenance guide and to obtain certain documents for the research needs.

Extensions and paths, otherwise, future research will focus around the contribution of EI to knowledge management, both in its knowing version (implicit and explicit knowledge) and in its knowledge version (epistemology of practice).

\section{REFERENCES}

Achab, B. \& Harrizi, D. (2013). Les défis de l'intelligence économique au Maroc. La Revue Gestion et Organisation, 5, 130-137.

Ampofo, J. A., Nassè, T. B., \& Akouwerabou, L. (2020). The effects of stress on performance of workers in Ghana health service in Wa municipal. International Journal of Management \& Entrepreneurship Research, 2(4), 212-230.

Arcep (2018). Rapports trimestriels d'activités T1, T2, T3 et T4.

Baumard, P. (1991). Stratégie et surveillance des environnements concurrentiels. Paris, PA: Elsevier Masson.

Bidan, M. (2017). Recherche et développement durable : Performance environnementale des systèmes d'information. Nantes, NA : LEMNA.

Carbonell, N., Nassè, T. B., \& Akouwerabou, D. (2020). African economic paradox: industrialization creating jobs and added value or active participation in global value chains: what solutions to develop for the less advanced and landlocked countries like Burkina Faso? International Journal of Advanced Economics, 2(1), 1-20.

Carbonell, N., Nassè, T. B., Briceno M., J., \& Ouédraogo, A. (2020). Rethinking recruitment methods in Africa for a better management: an evidence from businesses in Burkina Faso. International Journal of Social Sciences Perspectives, 7(2), 81-88. https://doi.org/https://doi.org/10.33094/7.2017.2020.72.81.88

D'Aveni, R. A. (1994). Hypercompetition : Managing dynamics of strategic maneuvering. New York, NY: The Free Press.

Dumez, H. (2011). Qu'est-ce que la recherche qualitative ? Le Libellio d'Aegis, 7(4), 47-58.

Le Moigne, J. L. (1977). La théorie du système général. Paris, PA: PUF. 
Martre, H. (1994). Intelligence économique et stratégie des entreprises. Paris, PA: Documentation française.

Nassè T. B. (2012). Succeeding in Church missionarial work in West Africa: the necessity of understanding the West African environment. Saarbrücken: Lambert Academic Publishing.

Nassè, B. T. (2016). L'équité interne dans la gestion de la relation client: une étude comparative quantitative de trois entreprises privées du Burkina Faso. Journal OuestAfricain des Sciences de Gestion, 1(1), 38 -54.

Nassè, B. T. (2018). Pratiques religieuses et comportement de consommation dans un contexte africain : une étude exploratoire sur les consommateurs au Burkina Faso. Thèse de Doctorat en sciences de Gestion, spécialité marketing. Ouagadougou, OU: Université Aube nouvelle en coopération avec l'Université Cheikh Anta Diop.

Nassè, T. B. (2019). Internal equity and customer relationship management in developing countries: A quantitative and a comparative study of three private companies in Burkina Faso. African Journal of Business Management, 13(1), 37-47.

Nassè, T. B. (2020). Religious beliefs, consumption and inter-religious differences and similarities: is syncretism in consumption a new religious dynamics? International Journal of Management \& Entrepreneurship Research, 2(2), 59-73.

Volle, M. (2014). Iconomie. Paris, PA: Xerfi Economica.

Wilensky, H. (1967). Organizational intelligence: knowledge and policy in government and industry. Basic Books.

\section{Acknowledgements}

The research team wants to acknowledge the support of the editorial board of the International Journal of Management \& Entrepreneurship Research and the different respondents and the Telecel Faso Company. We are also deeply indebted to Dr. Théophile Bindeouè Nassè for his steady support and contributions to this research project.

\section{Conflict of Interest Statement}

No conflict of interest has been declared by the different authors. 